\title{
Samvariation mellan systematiska räkningar och spontan rapportering av rastande vadare i Getteröns naturreservat
}

\author{
Covariation between systematic counts and spontaneous \\ reporting of staging waders at the Getterön Nature \\ Reserve, southwestern Sweden
}

Reino Andersson

Rödaledstigen 6, 432 53, Varberg, Sweden | samreinoandersson@gmail.com

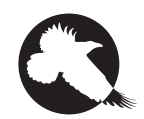

THIS PAPER is an attempt to describe how strong the covariation is between systematic counts and spontaneous reporting of staging waders at the Getterön Nature Reserve in southwestern Sweden. The material is based on systematic and spontaneous observations of twelve species of waders, made on the same days during the autumn migration in July-October 2010-2019. There is a significant positive correlation between the two methods for nine of twelve species. However, there is a large variation in the strength of the correlations, with the strongest correlation seen for Dunlin Calidris alpina. The Wood Sandpiper Tringa glareola, Green Sandpiper Tringa ochropus, and Little Stint Calidris minuta, on the other hand, show no significant correlations. This shows the difficulties in evaluating quantitative data of the wader occurrence at stopover areas such as Getterön. The variation in correlation between count methods between different species entails an uncertainty, which is probably due to low reliability in the spontaneous reporting. Thus, in the case of studies of staging waders based solely on spontaneous data, caution should be exercised.

Keywords: citizen science | Charadriiformes | shorebirds | stopover | survey methods 


\section{Introduktion}

Från Getteröns naturreservat föreligger två publicerade studier av rastande vadare. Åren 1973 till 1977 utförde Cederlund (1985) systematiska räkningar från tre olika punkter på reservatet, vilka upprepades på ett likartat sätt 2010 till 2013 (Andersson 2014, 2016). Dessa inventeringar redovisar vadarnas säsongsmässiga uppträdande, samt vissa jämförelser av de förändringar som ägt rum. Publicerade artiklar om rastande vadare är överlag fåtaliga i Sverige (Nilsson 1962, Gyllin 1963, 1965, Källander 1965, Ahlbom \& Haglund 1970, Wirdheim 1985, Svensson 2018). Därutöver återfinns övergripande presentationer, där vadare ingår som en del eller utvärderingar av ringmärkningsmaterial (t. ex. Myhrberg 1961, Holmbring 1970, Pehrsson m. fl. 1970, Cederlund 1975, Waldenström \& Lindström 2001, Hedenström 2004, Helseth m. fl. 2005a, 2005b, Iwajomo \& Hedenström 2011, Stedt \& Lindström 2012, Hedh \&
Hedenström 2016, Stigh \& Pettersson 2017, Hellström m.fl. 2018).

Många av dessa vadarstudier är exempel på hur amatörornitologer länge har spelat en stor roll för svensk faggelfaunistik (t. ex. Risberg 1990). I samband med uppkomsten av publika digitala databaser som är öppna för alla, har frågan aktualiserats om amatörernas roll för den vetenskapliga ornitologin. Medborgarforskning eller citizen science har blivit allt vanligare begrepp och åtföljts av en rad olika modeller internationellt, för att kunna utnyttja databasernas stora rapportmängder $\mathrm{i}$ vetenskapligt syfte. Nationella trendanalyser har gjorts av fåglars uppträdande under häckningsperioden, men även vintertid (t. ex. Sullivan m. fl. 2009, Dickinson m. fl. 2010, Snäll m. fl. 2011, Hochachka m. fl. 2012, Zbinden m.fl. 2014, Kamp m. fl. 2016, Henckel m. fl. 2020).

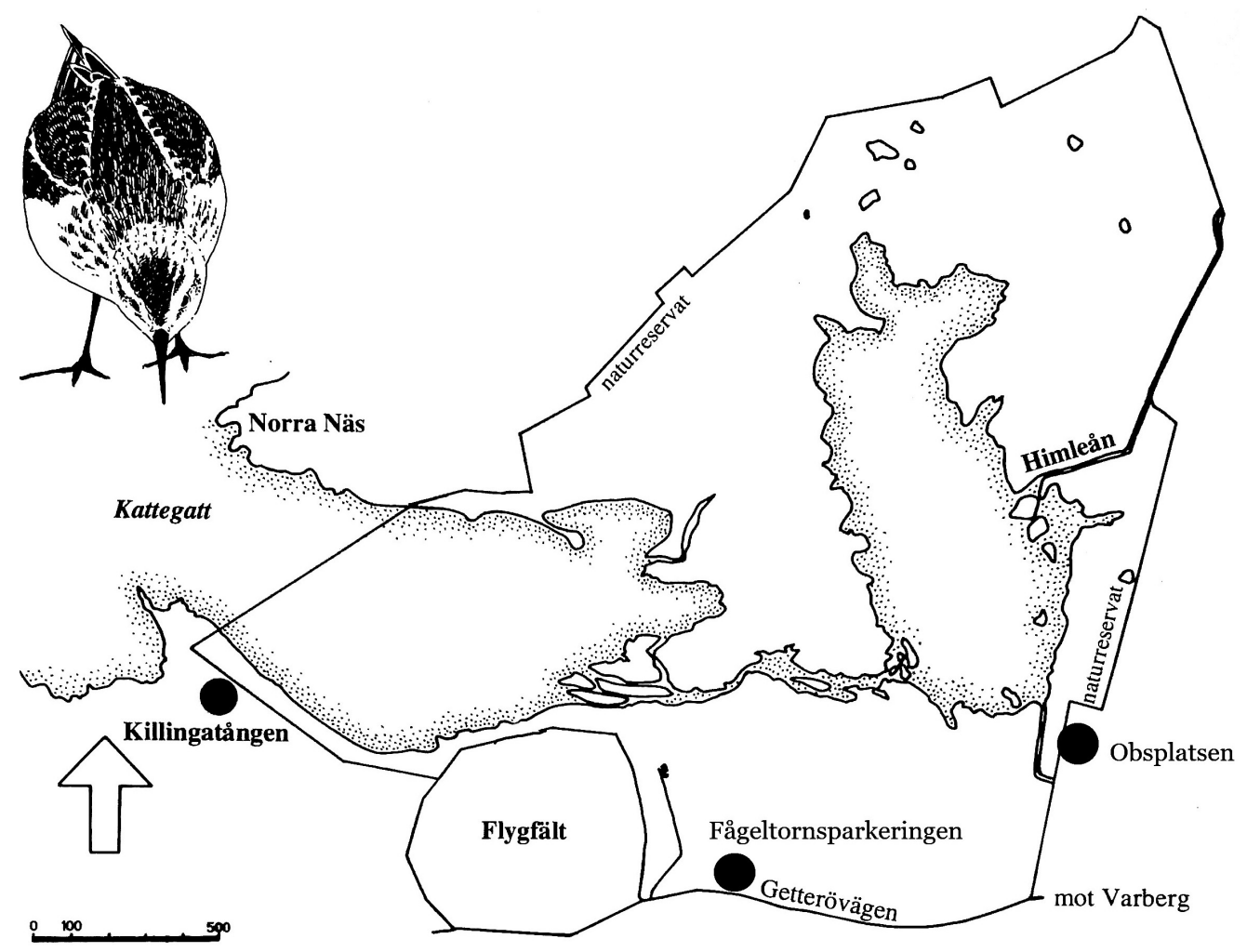

FIGUR 1. Karta över Getteröns naturreservat med de tre observationspunkterna utmärkta med fyllda cirklar. Illustration: Gunnar Pettersson. - Map of Getterön Nature Reserve with the three observation sites marked with filled circles. Illustration: Gunnar Pettersson. 
a

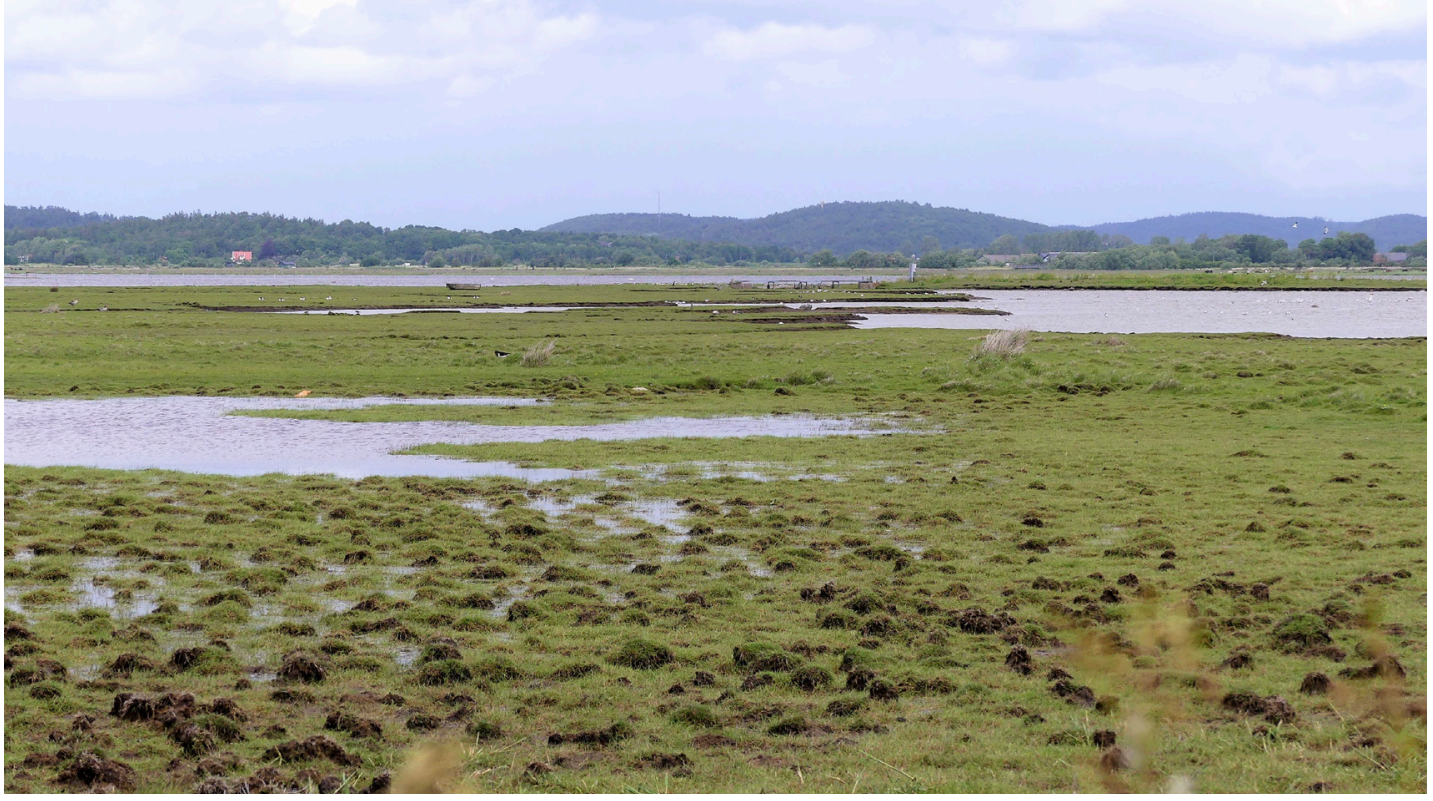

b
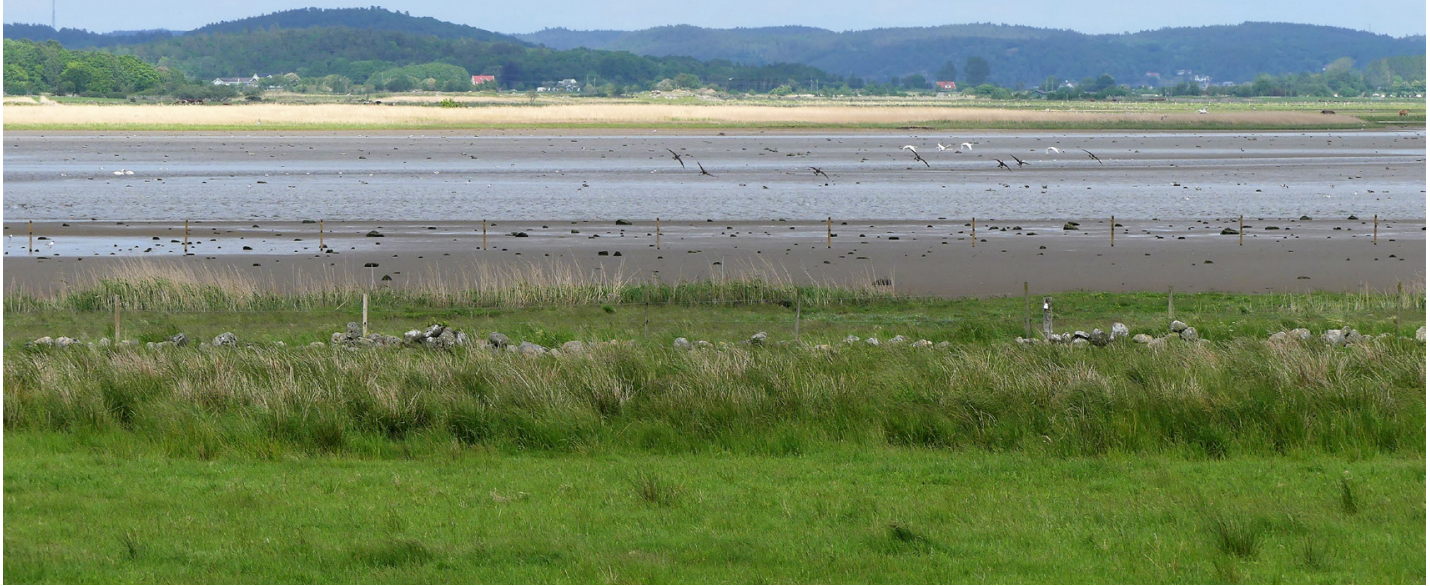

FIGUR 2. Vyer från observationsplatserna (a) Fågeltornsparkeringen och (b) Killingatången. Foto: Anette Andersson.

- Views from the observation sites (a) Fågeltornsparkeringen and (b) Killingatången. Photo: Anette Andersson. 
För flyttande vadare på enskilda rastlokaler saknas dock noggrannare metodstudier (jfr Ruete m. fl. 2017, van Brederode \& Roersma 2020). Däremot har mer omfattande skandinaviska räkningar av vadare gjorts i Danmark, vid Vadehavet och Tipperne (Laursen \& Frikke 2013, Meltofte \& Clausen 2016). Denna uppsats avser att beskriva hur stark samvariationen är mellan systematiska räkningar och spontan rapportering av rastande vadare i Getteröns naturreservat.

\section{Material och metoder}

Materialet baseras på systematiska och spontana observationer av tolv arter vadare, utförda samma dagar under höststräcket juli-oktober 2010-2019. Det inkluderar endast dagar med minst en observerad individ, eftersom det inte registrerats några nolldagar $\mathrm{i}$ det spontana materialet. För att få ett tillräckligt stort underlag begränsades arturvalet av att minst 25 dagar skulle ingå i studien. Då det endast omfattar rastande fåglar ingick inte några av de häckande vadararterna.

De systematiska räkningarna utfördes av författaren enligt ett förutbestämt schema från tre olika punkter (figur 1): observationsplatserna vid Naturum, Fågeltornsparkeringen (figur 2a) och Killingatången (figur 2b). Från dessa punkter kunde hela reservatet om cirka 350 hektar överblickas, även om det innebar långa avstånd till de norra delarna. En samlad och likartad värdering av maxantalen gjordes varje observationsdag utifrån dessa tre punkter. Data från spontana rapporter samlades in från databasen Artportalen (https://www.artportalen.se/) under sökordet "Getteröns naturreservat, Getterön, Hl". Dessa publika observationer har nästan uteslutande skett från någon eller några av de observationsplatser som gällt för de systematiska räkningarna. I de fall flera observatörer rapporterat samma dag har högsta värdet använts.

TABELL 1. Korrelationskoefficient för Spearmans rangkorrelation $\left(R_{s}\right), 95 \%$ konfidensintervall $(95 \% \mathrm{Cl})$ och antal jämförelser (N) för samtliga systematiska och spontana observationer gjorda samma dag.

- Correlation coefficient for Spearman's rank correlation $\left(R_{S}\right)$, $95 \%$ confidence interval (95\% Cl), and number of comparisons ( $N$ ) for all systematic and spontaneous observations made on the same day.

\begin{tabular}{|c|c|c|c|c|c|}
\hline \multicolumn{3}{|c|}{ Art Species } & \multirow[b]{2}{*}{$\mathrm{R}_{\mathrm{s}}$} & \multirow[b]{2}{*}{$95 \% \mathrm{Cl}$} & \multirow[b]{2}{*}{$\mathrm{N}$} \\
\hline $\begin{array}{l}\text { Svenskt namn } \\
\text { Swedish name }\end{array}$ & $\begin{array}{l}\text { Engelskt namn } \\
\text { English name }\end{array}$ & $\begin{array}{l}\text { Vetenskapligt namn } \\
\text { Scientific name }\end{array}$ & & & \\
\hline Storspov & Curlew & Numenius arquata & 0,47 & $0,20-0,67$ & 46 \\
\hline Myrspov & Bar-tailed Godwit & Limosa lapponica & 0,47 & $0,24-0,65$ & 57 \\
\hline Kustsnäppa & Red Knot & Calidris canutus & 0,58 & $0,27-0,78$ & 29 \\
\hline Brushane & Ruff & Calidris pugnax & 0,62 & $0,45-0,74$ & 73 \\
\hline Spovsnäppa & Curlew Sandpiper & Calidris ferruginea & 0,59 & $0,31-0,78$ & 33 \\
\hline Kärrsnäppa & Dunlin & Calidris alpina & 0,69 & $0,53-0,80$ & 61 \\
\hline Småsnäppa & Little Stint & Calidris minuta & 0,17 & $-0,22-0,51$ & 28 \\
\hline Skogssnäppa & Green Sandpiper & Tringa ochropus & 0,26 & $-0,15-0,60$ & 25 \\
\hline Grönbena & Wood Sandpiper & Tringa glareola & 0,28 & $-0,05-0,55$ & 37 \\
\hline Svartsnäppa & Spotted Redshank & Tringa erythropus & 0,66 & $0,48-0,79$ & 55 \\
\hline Gluttsnäppa & Greenshank & Tringa nebularia & 0,46 & $0,23-0,65$ & 57 \\
\hline Kustpipare & Grey Plover & Pluvialis squatarola & 0,48 & $0,21-0,68$ & 44 \\
\hline Alla arter & All species & & 0,59 & $0,54-0,65$ & 545 \\
\hline $\begin{array}{l}\text { Inom samma } \\
\text { fyratimmarsperiod }\end{array}$ & $\begin{array}{l}\text { Within the same } \\
\text { four-hour period }\end{array}$ & & 0,49 & $0,38-0,59$ & 208 \\
\hline $\begin{array}{l}\text { Mellan olika } \\
\text { fyratimmarsperioder }\end{array}$ & $\begin{array}{l}\text { Between different } \\
\text { four-hour periods }\end{array}$ & & 0,67 & $0,55-0,76$ & 113 \\
\hline
\end{tabular}


Observationernas tidsmässiga fördelning över dygnet har delats upp i fyratimmarsperioder och utgår från morgon 06:00-10:00, middag 10:00-14:00, eftermiddag 14:00-18:00 och kväll 18:00-22:00. Då vissa dagar i det spontana materialet saknar tidsangivelse, motsvarar denna uppdelning $59 \%$ av samtliga räkningsdagar.

För var och en av arterna presenteras en graf som visar antalet systematiskt räknade fåglar på den horisontella axeln och spontant observerade på den vertikala (figur 3). Varje datapunkt i graferna representerar således båda metodernas antal för en och samma dag. För att visa sambandets styrka mellan de båda observationsmetoderna, presenteras Spearmans rangkorrelationskoefficient samt tillhörande $95 \%$ konfidensintervall (tabell 1).

\section{Resultat}

Det finns en signifikant positiv korrelation mellan de båda räkningsmetoderna för nio av tolv arter. Det förekommer dock en betydande variation i sambandens styrka (tabell 1), där kärrsnäppa Calidris alpina uppnår starkast korrelation (figur $3 f$ ), följd av svartsnäppa Tringa erythropus (figur 3j), som också uppvisar relativt höga värden. Grönbena Tringa glareola (figur $3 \mathrm{i}$ ), skogssnäppa Tringa ochropus (figur $3 \mathrm{~h}$ ) och småsnäppa Calidris minuta (figur $3 \mathrm{~g}$ ) uppvisar däremot inga statistiskt signifikanta samband. Av de systematiska och spontana observationer som har tidsangivelser i denna studie faller $65 \%$ inom samma fyratimmarsintervall, medan $35 \%$ gjordes under olika fyratimmarsperioder. I tabell 1 , där korrelationskoefficienten för de tolv studerade arterna framgår, kan utläsas att observationer inom samma fyratimmarsintervaller inte uppvisar högre korrelation än de som gjorts under olika perioder samma dag. Figur 3 redovisar graferna över antalet systematiskt och spontant observerade individer under samma dag.

\section{Diskussion}

De erhållna resultaten från Getteröns naturreservat ger i varierande grad stöd för en signifikant samvariation mellan systematiska räkningar och spontan rapportering hos vissa arter, men inte hos andra. Detta trots att det rör sig om relativt stora och lättupptäckta fåglar, som ofta uppehåller sig stationärt inom ett begränsat område då de rastar och födosöker. Vad skillnaderna i korrelation mellan olika arter kan bero på går inte att fastslå utifrån dessa data. Man skulle spekulativt kunna tänka sig att vanligare arter, som kärrsnäppa, är mindre intressanta att räkna än exempelvis kustpipare Pluvialis squatarola och småsnäppa. Likaså är det möjligt att större, färggranna och mer synliga fåglar som myrspov Limosa lapponica skulle registreras i högre utsträckning i det spontana materialet. Resultaten i denna studie visar dock att så inte är fallet (tabell 1, figur 3).

En annan bidragande orsak till skillnader i korrelation skulle kunna vara olika kompetens eller ambitioner hos observatörerna. Utöver skillnader i artkunskap är det tänkbart att nytillkomna faggelintresserade värderar en observation annorlunda än de som är mer erfarna. För flertalet observatörer handlar det sannolikt om att man rapporterar de antal som råkar ses från en viss plats, eller endast registrerar en artobservation med en individ. Även rastlokalens storlek skulle kunna ha betydelse för skillnader i resultaten.

En svaghet med föreliggande redovisning skulle kunna vara att räkningarna gjorts under olika tidpunkter på dagen, med reellt förändrade antal av rastande fåglar. Vadare kan uppvisa en viss variation i antal även under ett och samma dygn, i synnerhet vid speciella vädersituationer (t. ex. Gyllin 1965, Alerstam 1982). Resultaten visar dock inga påtagliga skillnader i korrelation, beroende på när observationerna gjorts under dygnet (tabell 1). En annan faktor som kan påverka resultaten är att olika dellokaler för Getterön förekommer i Artportalen. Sökbegreppet "Getteröns naturreservat, Getterön, $\mathrm{Hl}$ " har valts för den spontana sökningen, då det har i särklass flest noteringar och i likhet med de systematiska räkningarna avser hela reservatet.

När det gäller nationella populationstrender hos häckande fåglar föreligger några skandinaviska jäm-

FIGUR 3 (nästa sida). Förhållandet mellan antalet systematiskt och spontant observerade individer under samma dag av tolv vadararter. Den diagonala streckade linjen motsvarar ett 1:1-förhållande, där lika många individer räknades in vid systematiska räkningar som vid spontana rapporter. $\mathrm{R}_{\mathrm{S}}$ anger Spearmans rangkorrelationskoefficient (se tabell 1 för $95 \%$ konfidensintervall) och NS indikerar ickesignifikant korrelation.

- (next page) The relationship between the number of individuals systematically and spontaneously observed during the same day, for twelve shorebird species. The dashed line signifies a 1:1 relationship, where the same number of individuals was noted in the systematic counts as in the reports of spontaneous observations. $R_{s}$ specifies the Spearman rank correlation coefficient (see Table 1 for $95 \%$ confidence intervals) and NS indicates non-significant correlation. 

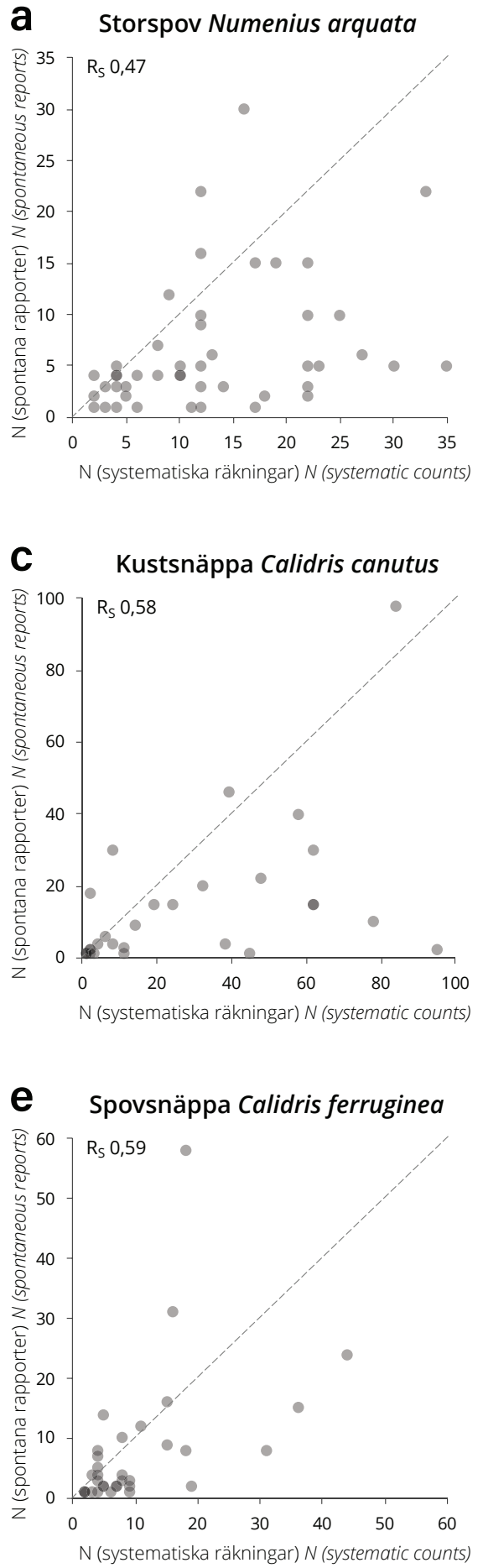
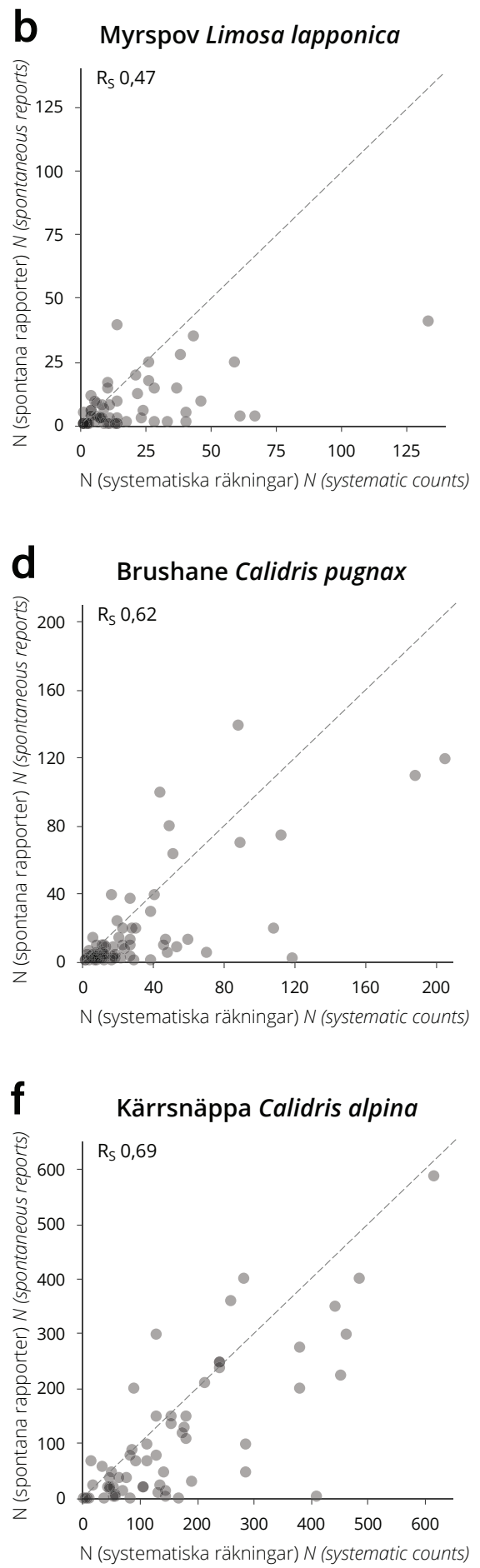

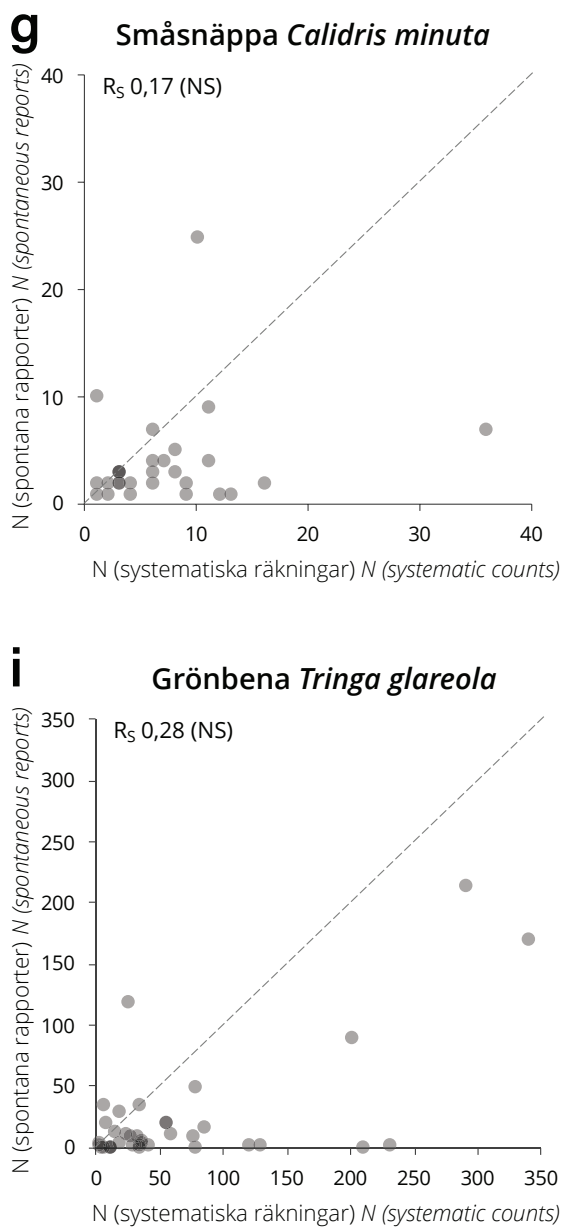

\section{K Gluttsnäppa Tringa nebularia}

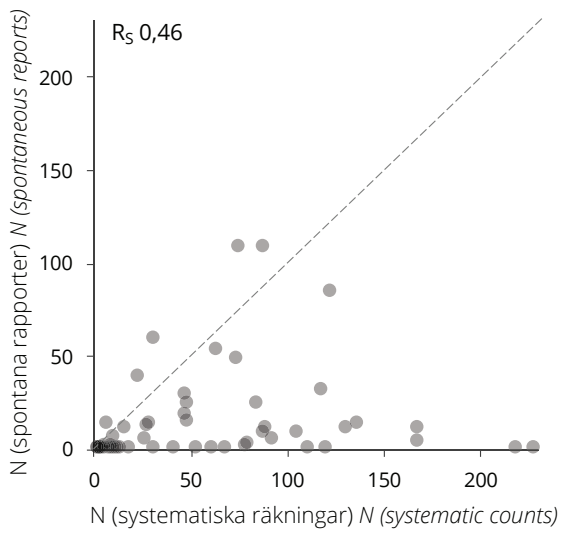

h Skogssnäppa Tringa ochropus
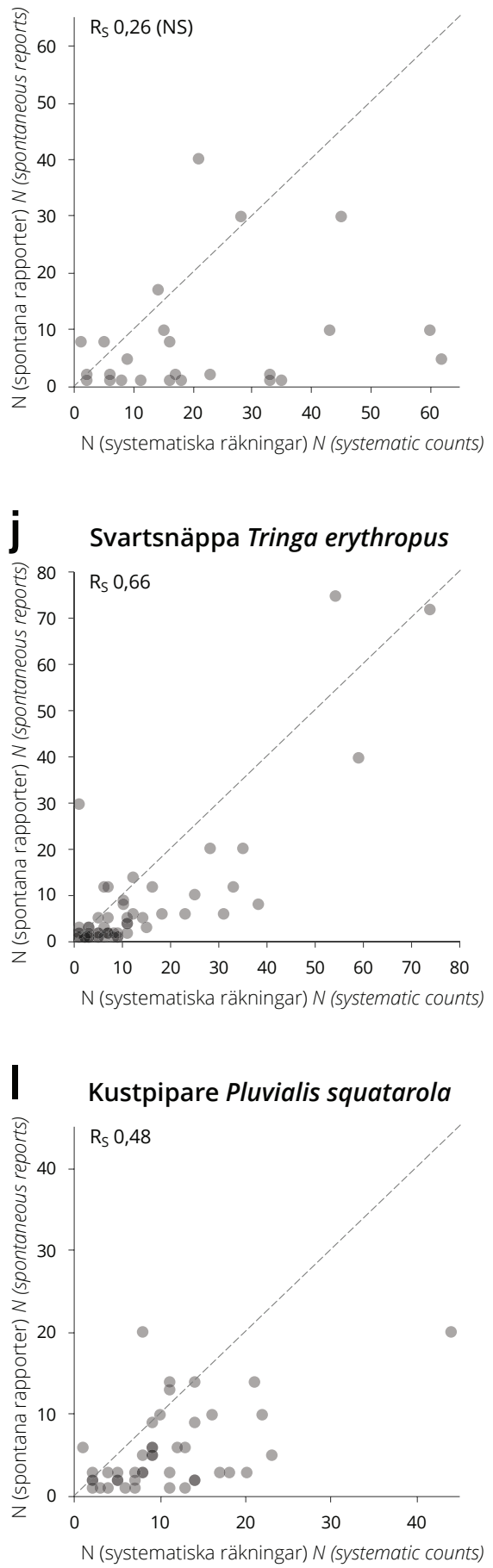

FIGUR 3 fortsatt continued 
förelser mellan standardiserade taxeringar och publika data. Kamp m. fl. (2016) fann en generellt positiv korrelation mellan metoderna i danska fagelpopulationer, samtidigt som det förekom stor variation mellan arterna. Nedgångar hos många vanliga arter upptäcktes inte med publik, ostrukturerade data. Istället klassificerades en majoritet av dem som stabila eller ökande. Likaså redovisar Snäll m.fl. (2011) en stor variation i korrelation mellan olika arter. Som förklaring anges bland annat skiftande rapportvillighet och täckningsgrad för vanliga respektive ovanliga arter mellan de olika metoderna, samt skillnader i observatörers kompetens. Henckel m. fl. (2020) anger en god samstämmighet mellan systematiska och spontana data hos vissa skogsfaglar, i synnerhet för ovanligare arter.

Denna uppsats visar på svårigheterna att värdera kvantitativa data av vadarförekomsten på rastlokaler som Getterön. Variationen i uppmätta samband mellan olika arter medför en osäkerhet, som torde bero på låg tillförlitlighet i den spontana rapporteringen. När det gäller studier av rastande vadare som baseras enbart på spontana data bör därmed försiktighet iakttas tills förbättrad kunskap har erhållits.

\section{Tack}

Tack till Robin Andersson och Bo Nielsen som granskat manuskriptet. Tack också till Ornis Svecicas referenter, samt Jimmy Stigh, Sören Svensson, Lars-Åke Flodin och Kjell Wallin för givande diskussioner.

\section{Referenser}

Ahlbom B \& Haglund T. 1970. Rastande vadare vid Eskilstuna reningsverk under 1960-talet. Fåglar i Sörmland 3: 25-37.

Alerstam T. 1982. Fågelflyttning. Bokförlaget Signum, Uppsala.

Andersson R. 2014. Viktigt vatten för vadare. Vår Fågelvärld 2/2014: 28-35.

van Brederode NE \& Roersma HJ. 2020. Turnover, passage population size and flight range of juvenile Ruddy Turnstones at a non-estuarine staging site in the Netherlands. Ardea 108: 213-222. https://doi.org/10.5253/arde.v108i2.a9

Cederlund C-G. 1975. Återfynd av vid Getterön ringmärkta enkelbeckasiner. Meddelande från Getteröns fagelstation 11: 2-14.

Cederlund C-G. 1985. Rastande vadare vid Getterön under fem år, 1973-1977. Vår Fågelvärld 44: 61-77.

Dickinson J, Zuckerberg B \& Bonter DN. 2010. Citizen science as an ecological research tool: challenges and benefits. Annual Review of Ecology, Evolution, and Systematics 41: 149-172. https://doi. org/10.1146/annurev-ecolsys-102209-144636

Gyllin R. 1963. Observationer av vadare under fem år vid Oset. Fauna och Flora 59: 153-184.

Gyllin R. 1965. Några synpunkter på förhållandet mellan rastande och sträckande vadare i inlandet. Vår Fågelvärld 24: 218-234.

Hedenström A. 2004. Migration and morphometrics of Temminck's Stint Calidris temminckii at Ottenby, southern Sweden. Ringing \& Migration 22: 51-58. https://doi.org/10.1080/03078698.2004.967 4310

Hedh L \& Hedenström A. 2016. Autumn migration strategies and trapping numbers in the Common Ringed Plover Charadrius hiaticula in southern Sweden. Ardea 104: 227-237. https://doi. org/10.5253/arde.v104i3.a3

Hellström M, Ottvall R, Andersson A, Lilja Nordin T, Waldenström $\mathrm{J} \&$ Lindström $\AA$. 2018. Fågelräkning och ringmärkning vid Ottenby faggelstation 2017. Rapport, Ottenby fågelstation.

Helseth A, Lindström Å \& Stervander M. 2005a. Southward migration and fuel deposition of Red Knots Calidris canutus. Ardea 93: 213-24.

Helseth A, Stervander M \& Waldenström J. 2005. Migration patterns, population trends and morphometries of Ruddy Turnstones Arenaria interpres passing through Ottenby in south-eastern Sweden. Ornis Svecica 15: 63-72. https://doi.org/10.34080/os.v15.22411

Henckel L, Bradter U, Jönsson M, Isaac NJB \& Snäll T. 2o2o. Assessing the usefulness of citizen science data for habitat suitability modelling: Opportunistic reporting versus sampling based on a systematic protocol. Diversity and Distributions 26: 1276-1290. https://doi.org/10.1111/ddi.13128

Hochachka WM, Fink D, Hutchinson RA, Sheldon D, Wong W-K \& Kelling S. 2012. Data-intensive science applied to broad-scale citizen science. Trends in Ecology and Evolution 27: 130-137. https://doi.org/10.1016/j.tree.2011.11.006

Holmbring J-Å. 1970. Fåglarna vid sjön Roxen 1953-1968. Vår Fågelvärld 29: 179-222.

Iwajomo SB \& Hedenström A. 2011. Migration patterns and morphometrics of Common Sandpipers Actitis hypoleucos at Ottenby, southeastern Sweden. Ringing \& Migration 26: 38-47. https://doi.org/10.1080/03078698.2011.586509

Kamp J, Oppel S, Heldbjerg H, Nyegaard T \& Donald PF. 2016. Unstructured citizen science data fail to detect long-term population declines of common birds in Denmark. Diversity and Distributions 22: 1024-1035. https://doi.org/10.1111/ddi.12463

Källander H. 1965. Exempel på tillfälliga rastplatsers betydelse för iakttagelser av vadarsträck. Fauna och Flora 6o: 63-67.

Laursen K \& Frikke J. 2013. Rastende vandfugle i Vadehavet 1980-2010. Dansk Ornitologisk Forenings Tidskrift 107: 1-184.

Meltofte H \& Clausen P. 2016. Trends in staging waders on the Tipperne Reserve, western Denmark, 1929-2014. Dansk Ornitologisk Forenings Tidskrift 110: 1-72.

Myhrberg H. 1961. Grönbenans (Tringa glareola) sträck genom Europa. Vår Fågelvärld 20: 115-145.

Nilsson L. 1962. Vadarsträcket vid Hullsjön 1959 och dess beroende av temperaturen. Vår Fågelvärld 21: 15-25.

Pehrsson O \& Unger U. 1970. Inventering av häckande, rastande och övervintrande sjöfågel, vadare m. fl. utmed Hallandskusten. Zoologiska Institutionen, Göteborgs universitet, Göteborg.

Pettersson G, Andersson R \& Flodin L-Å. 2016. Fåglarnas Getterön. Sveriges Ornitologiska Förening, Halmstad.

Risberg L (red). 1990. Sveriges fåglar. 2:a upplagan. Sveriges Ornitologiska Förening, Stockholm.

Ruete A, Pärt T, Berg Å \& Knape J. 2017. Exploiting opportunistic observations to estimate changes in seasonal site use: An example with wetland birds. Ecology and Evolution 7: 5632-5644. https://doi. org/10.1002/ece3.3100 
Snäll T, Kindvall O, Nilsson J \& Pärt T. 2011. Evaluating citizen-based presence data for bird monitoring. Biological Conservation 144: 804-810. https://doi.org/10.1016/j.biocon.2010.11.010

Stedt J \& Lindström Å. 2012. Spring fuelling by arctic Dunlins Calidris a. alpina in the southern Baltic and the potential role of a changing climate. Ornis Svecica 22: 80-92. https://doi.org/10.34080/ os.v22.22586

Stigh J \& Pettersson G. 2017. Bua-Båtafjorden, Väröhalvön $i$ Halland: Fåglar och natur samt en frekvensstudie av fågelarter 2004-2015. Winestone, Frillesås.

Sullivan BL, Wood CL, Iliff MJ, Bonney RE, Fink D \& Kelling S. 2009. eBird: a citizen-based bird observation network in the biological sciences. Biological Conservation 142: 2282-2292. https://doi.org/10.1016/j.biocon.2009.05.006
Svensson S. 2018. Sewage sedimentation ponds-a lost bird paradise: a nostalgic return visit and case study. Ornis Svecica 28: 81-86. https://doi.org/10.34080/os.v28.19535

Waldenström J \& Lindström Å. 2001. Migration and morphometrics of the Broad-billed Sandpiper Limicola falcinellus at Ottenby, southern Sweden, 1950-2000. Ornis Fennica 78: 184-192.

Wirdheim A. 1985. Vadarnas vårsträck i Påarp. Fåglar i södra Halland 24: 11-21.

Zbinden N, Kery M, Häfliger G, Schmid H \& Keller V. 2014. A resampling-based method for effort correction in abundance trend analyses from opportunistic biological records. Bird Study 61: 506-517. https://doi.org/10.1080/00063657.2014.969679

\section{English summary}

This paper attempts to describe the strength of the covariation between systematic counts and spontaneous reporting of staging waders at the stopover site Getterön Nature Reserve in southwest Sweden. The material is based on systematic and spontaneous observations of twelve waders species, performed on the same days during the autumn migration in July-October 2010-2019. The data set only includes days during which at least one individual was observed, as no zero-days have been recorded in the material of spontaneous sightings. In order to obtain a sufficiently large data set, the selection of species for the study was limited to comprise at least 25 days with observations. As I focused on staging birds, none of the breeding wader species were selected for the study.

The systematic counts were performed by the author according to a predetermined schedule from three different observation sites in the 350-hectare nature reserve (Figures 1-2). An overall assessment of the maximum number was made on each observation day, based on counts from these three points in a standardized way. Spontaneously reported data were collected from the database Artportalen (https://www.artportalen.se/) using the keyword "Getteröns naturreservat, Getterön, $\mathrm{Hl}$ ". These public observations have been made almost exclusively from one or more of the observation sites that are used for the systematic counts. In cases where several observers had submitted reports for the same day, the highest value was used. The distribution of observations over the day was classified into four-hour periods. As some observations in the spontaneous ma- terial lack a time indication, the time-classified material corresponds to $59 \%$ of all observation days. To show the strength of the relationship between the two observation methods, a graph is presented for each species (Figure 3), and Spearman's rank correlation coefficients and the associated $95 \%$ confidence intervals are presented in Table 1.

There is a significant positive correlation between the two count methods for nine of twelve species. However, there is a large variation in the strength of the correlations, with the Dunlin Calidris alpina (Figure $3 \mathrm{f}$ ) demonstrating the strongest correlation. The Wood Sandpiper Tringa glareola (Figure 3i), Green Sandpiper Tringa ochropus (Figure $3 \mathrm{~h}$ ) and Little Stint Calidris minuta (Figure $3 \mathrm{~g}$ ), on the other hand, show no significant correlations. The reason for the differences in correlation between different species cannot be determined from these data. One could speculatively imagine that more common species, such as Dunlin, are less interesting to count than less frequently observed species, for example Grey Plover Pluvialis squatarola and Little Stint. Likewise, larger, colorful, and more visible birds such as Bar-tailed Godwit Limosa lapponica could be registered to a greater extent in the spontaneous material. However, the results lend no support to such postulations (Table 1, Figure 3).

Another contributing factor could be the different skills or ambitions of the observers. In addition to differences in species knowledge, it is conceivable that new birdwatchers regard an observation differently than those who are more experienced. For most observers, 
it is probably a matter of reporting the numbers that could be seen from a certain place, or only registering a species by reporting and observation of one individual. The size of the staging area could also be important for differences in the results.

A weakness with the present report could be that the counts were made at different times of the day, with actual changes in the numbers of staging birds between time periods. Of the systematic and spontaneous observations that have time indications in this study, however, $65 \%$ are relatively similar in correlation over the day (Table 1). Another factor that could affect the results is that different subareas of Getterön appear in the database Artportalen. The search term "Getteröns naturreservat, Getterön, $\mathrm{Hl}$ " was chosen for the spontaneous search, as it has by far the most records and, like the systematic counts, refers to the entire reserve.

The results obtained from the Getterön Nature Reserve provide varying degrees of support for significant correlations between systematic counts and spontaneous reporting in some wader species but not in others. This is despite the fact that waders are relatively large and easily detected birds, which often stay stationary in a limited area when staging and foraging. With regard to national population trends in breeding birds, there are some Scandinavian comparisons between standardized assessments and public data. Kamp et al. (2016) found a generally positive correlation between the methods in Danish bird populations, but there was great variation between species. Declines in many common species were not detected with public, unstructured data. Instead, a majority of them were classified as stable or increasing. Moreover, Snäll et al. (2011) account for a large variation in correlation between different species. Among other things, this can be explained by a difference in the willingness to report, and in the degree of coverage, between common and unusual species in the different methods, as well as differences in observers' competence. Henckel et al. (2020) show a high coherence between the methods for some forest birds, especially for uncommon species.

This study highlights the difficulties in evaluating quantitative data on the occurrence of waders in staging areas such as Getterön. The variation in measured relationships between different species entails an uncertainty, which is probably due to low reliability in the spontaneous reporting. Thus, in the case of studies of staging waders based solely on spontaneous data, caution should be exercised until improved knowledge has been obtained.

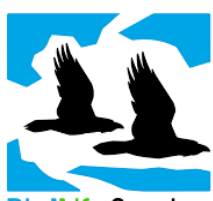

Birdlife Sverige

Ornis Svecica (ISSN 2003-2633) is an open access, peer-reviewed scientific journal published in English and Swedish by BirdLife Sweden. It covers all aspects of ornithology, and welcomes contributions from scientists as well as non-professional ornithologists. Accepted articles are published at no charge to the authors. Read papers or make a submission at os.birdlife.se.

Ornis Svecica (ISSN 2003-2633) är en fritt tillgänglig granskad vetenskaplig tidskrift som ges ut på svenska och engelska av BirdLife Sverige. Den täcker ornitologins alla områden och välkomnar bidrag från såväl forskare som icke-professionella ornitologer. Accepterade uppsatser publiceras utan kostnad för författarna. Läs uppsatser eller skicka in ditt bidrag på os.birdlife.se. 